\title{
新潟油田地域新第三系堆積岩中の海緑石について*
}

\author{
青柳宏 一** \\ （昭和 40 年 3 月 23 日受理）

\section{Glauconite from the Sedimentary Rocks of Neogene Tertiary System in Niigata Oil Field Area}

By

Kooichi AOYAGI

\begin{abstract}
In this paper, the writer describes the mineralogical study of glauconite from the various sedimentary rocks of Neogene Tertiary system in Niigata oil field area by the methods of optical observation and X-ray diflraction analysis, and lastly he concludes as follows:

1) These glauconite samples are classified into mica like type ( $\left.a_{1}, a_{2}\right)$, montmorillonite-illite mixed layer like type $\left(b_{1}, b_{2}\right)$, montmorillonite like type (C) and mineral mixtured type (D).

2) It is considered they must be derived from such a source materials as volcanic detritus.

3) Glauconitization will be promoted strongly in an anaerobic sedimentary environment having a larger quantity of organic materials and a slower sedimentary velocity with lesser sediments, because the sufficient contact action by sea water is necessary for glauconite formation.

4) As a similar glauconite are formed in a resembling environment, so the correlation by using glauconite is available only such a formations which has deposited in the same basin having a fixed environment.
\end{abstract}

\section{1. 序論}

海緑石は，元来，主として海成堆積岩中に産する挤片 を有する球形状***の解緑色鉣物粘に対する総称として 用いられてきた。

この海緑石に対する鈆物学的な定義は, 種々の研究者 によりなされているが, 須滕(8)（1953）は，一般に鮮緑

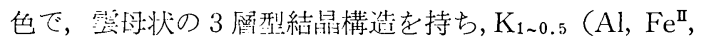
$\left.\mathrm{Fe}^{\mathrm{II}}, \mathrm{Mg}\right)_{2}(\mathrm{Si}, \mathrm{Al})_{4} \mathrm{O}_{10}(\mathrm{OH})_{2} \cdot n \mathrm{H}_{2} \mathrm{O}$ の化学絽.成を有する

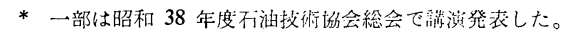

** 不油瓷源阙発 (株) 技術研究所

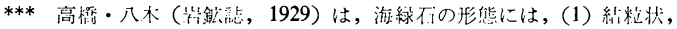

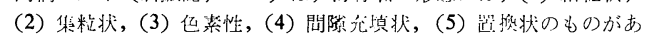
り，(1)，(2) では主として球形状を早するが，(3)，(4)，(5) は楽 々になると㟍告している。
ものと述べている。

近年来, 海緑石についての認識が進み, さらに研究方 法の進少に相伴なって，従来海緑石と称されていたもの には，鉱物学的意味での海緑石以外にそれと全く異種の 鉱物，例えば緑泥石などがあり，また異種の鉱物と海緑 石との中問生成物もあることが認められてきた。

この海緑石研究の歴史は非常に古く，19 世紀林に Murray 抢よび Renard (1891) などによりすでに研究が 始められて抢り，その後も Grunner (1935), Galliher (1939), Hendricks および Ross (1941), Light (1952), Grim (1953), Cloud (4) (1955), Burst ${ }^{(3)}$ （1958）など多 くの研究者達が, 游緑石の起源, 形成, 性質, 形態など について㾏々の報些を行なっている。

わが国においては，高橋・八木（1929）が本邦産海緑 
第 1 図紫露寺～小千谷坑井地質柱状図

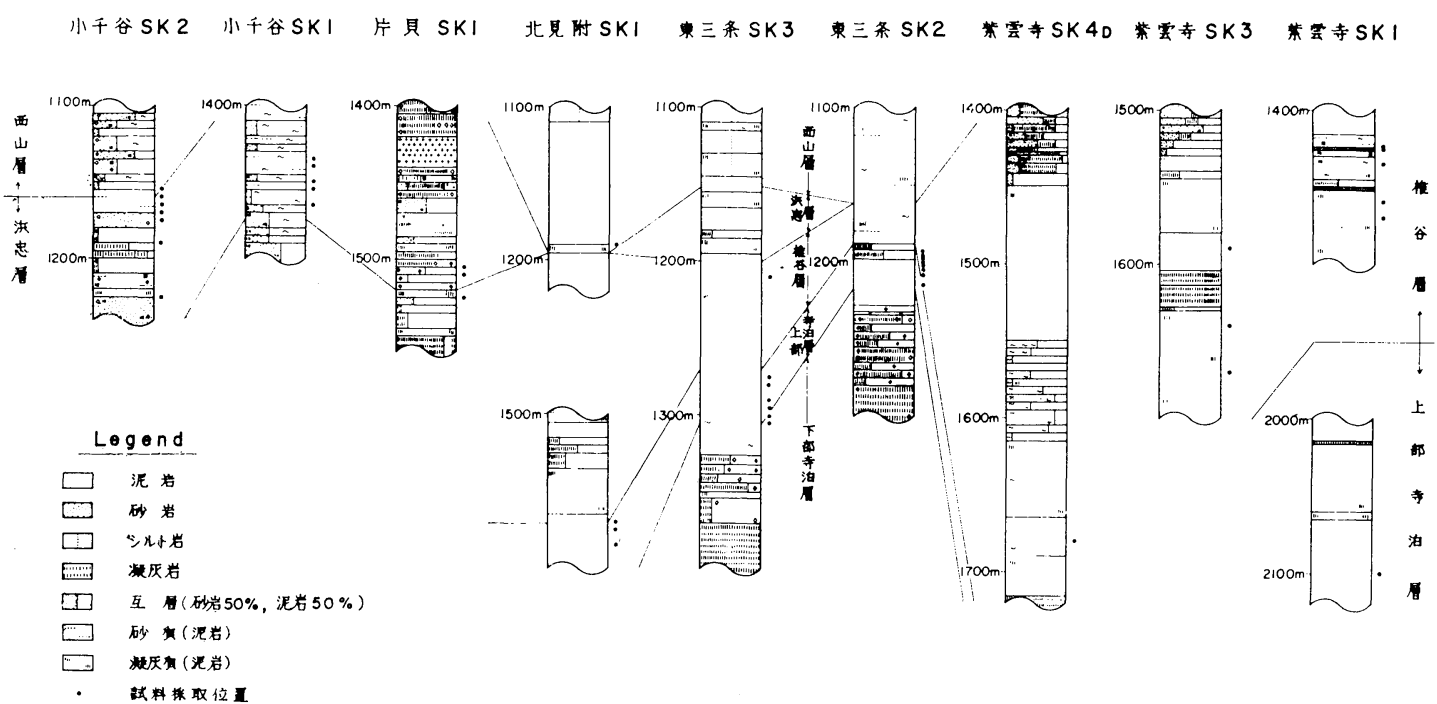

石について㥍れた報告をしている以外には比較的少な くわずかに北崎・市田（1951）の能登地方の海線石に ついての研究(6), 樹下 ${ }^{(5)}$ (1962), 彗柳(1) (1963) の基日 本含油新第三系堆積岩中の海緑石についての研究などが 挙げられるに過ぎない。

これらの研究者達の報告によれば，海緑石の分布賎围 は非常に広く, 罩位学的にはカンブリアン紀から現世ま でのそして地理学的には極地から熟州地域までの籁用に 存在していることが明らかにされている。また海線石 は，その生成ならびに移動集積の際に，種々の倠樻团子 (塩分浱度・酸素供給量・有機物量・哚度・温度・淌乱 流・根源物質・堆積物流入量など）が影響すると考えら れるので，現低地廨中にみられる海緑石は，堆樻垨にお けるそれらの因子を綜合した環境を示すものであること が認められている。

とくに Burst ${ }^{(3)}$ (1958) は, 准積罢境の差が海緑石化 を通じてその結昆度の差となってあらわれることを指摘

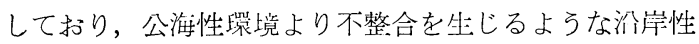

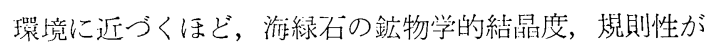
高くなると述へててい*。

したがって，ある地序中の海緑石を知ることにより， その地層の堆稓環境の解釈がある程度可能となり，また 同様な堆積環境で形成された海緑石が比較的類似の結昆 形態を有することより，これを追跡，対比の面に応用し ようとする徑みがなされている。

笵者は 1961 年より新潟盎地の含油新第三系堆䅪岩に

* Cloud (4) (1955) は湤綾们は主として㳀游性のものであるが，か なり涂い場所に打いても生成されると边べている。
座する海緑石について，主としてX線回析分析による研 究を行なってきたが，次のような絬果を得たので，ここ にまとめて報告する。

\section{2. 研 究 方 法}

この研究に使用した試料は，石油凟源開発（株）の紫 坛叔 SK.1·SK.3.SK. 4 D, 東三条 SK.2.SK.3, 北見 附 SK.1, 片貝 SK.1, 小千谷 SK.1·SK.2 の坑井カッ テイングおよびコア中より得たものであり，これらの産 状については第 1 裴に詳しく揭げてある。また，紫雲侍 〜小千谷沆井地質朴:状図は第 1 図に示す通りである。

\section{1. 海緑石粒の撰別}

原岩就料をクラッシャーに入れ，小正大に破硴した後， ローラーミルまたはミキサーにより各造岩精子に分漓す る。これを 60 メッシュの篩にか忖, 籂に残ったものを 双继顛微鏿で観祭しながら海緑石粒を撰別する。

\section{2. 海緑石粒の光学的観察}

これらの撰別された海緑石は，第 1 表に示す如く，光 沢のある竓緑色青黄色の䊀子で不透朋なものである。ま た第 2 図の頙微鏡冚真で吻らかなように，通常球形で裂 片を有しており，時に有孔虫化石に類似の形態を呈する ものもあり，その大きさは直径 $0.5 \mathrm{~mm}$ 以下のものと, $1 \mathrm{~mm}$ 以下のものとの 2 種類が存在している。

\subsection{X 線回折分析法}

撰別した海緑石試料を乳鉢に入れ，指頭でふれてざら

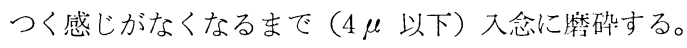
通常剤料を多量に得ることが团難であるので, 海緑不 の回折線を強めて判定を容易ならしめるために, 粉末試 
第 1 表 海緑石拭料の啟状

\begin{tabular}{|c|c|c|c|c|c|}
\hline 坑 \# & 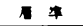 & 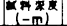 & 咥料の外现 & 母石の若相 & 曲若の光虫 \\
\hline \multirow{6}{*}{ 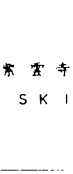 } & \multirow{5}{*}{ 椎谷量 } & 1424 & 睛枆厌色 & \multirow{2}{*}{ 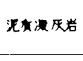 } & \multirow{2}{*}{$\begin{array}{l}\text { Méplophrogmoides ctr. } \\
\text { subgroloso }\end{array}$} \\
\hline & & 1425 & a & & \\
\hline & & 1435 & 资程我色 & \multirow{3}{*}{ 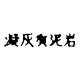 } & \multirow{3}{*}{$\begin{array}{l}\text { Mortinottiola communis } \\
\text { Epistminella puccello } \\
\text { Bulimina pupoides }\end{array}$} \\
\hline & & 1460 & $"$ & & \\
\hline & & 1470 & . & & \\
\hline & 上部泊酒 & 2100 & . & 晴质色况光 & $\begin{array}{l}\text { Angulogertine wokozurcensis } \\
\text { Urigering aR. }\end{array}$ \\
\hline \multirow{3}{*}{$\begin{array}{rrr}\text { * } & 5 & \\
S & k & 3\end{array}$} & \multirow{3}{*}{ 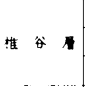 } & 1590 & 反 瓜 & 相反巴港若 & \multirow{3}{*}{$\begin{array}{l}\text { Cycliomina puccelila } \\
\text { Bulimina pupoides } \\
\text { Miliammo echigoensis }\end{array}$} \\
\hline & & 1640 & 溇极灰已 & \multirow[t]{2}{*}{ 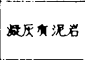 } & \\
\hline & & 1670 & A 厌色 & & \\
\hline \multirow{4}{*}{ * $S^{\pi} \quad \stackrel{4}{4}$} & 棋谷 & {$\left[\begin{array}{llll}1 & 6 & 8 & 0\end{array}\right]$} & 䜊相厉色 & 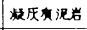 & $\begin{array}{l}\text { Mortinothilila communis } \\
\text { Epitmina dilo puccellos }\end{array}$ \\
\hline & \multirow{8}{*}{ 上钣暂洝 } & 11193 & 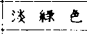 & \multirow{4}{*}{ 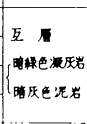 } & \multirow{3}{*}{$\begin{array}{l}\text { Haplophrogmaides cfr } \\
\text { eubgroloso } \\
\text { Uvigerino akitaensis } \\
\text { Angulogerino kokozuroensis }\end{array}$} \\
\hline & & 1196 & 涹和色 & & \\
\hline & & 11197 & ." & & \\
\hline \multirow[t]{2}{*}{ 茨 } & & 1198 & 波熋色 & & \multirow{5}{*}{$\begin{array}{l}\text { Spirosigmoilinella } \\
\text { compresso } \\
\text { Dorothia sp. } \\
\text { Martinotile llo communis }\end{array}$} \\
\hline & & 1200 & 波畨陡e & \multirow{4}{*}{ 暗斥色泥右 } & \\
\hline \multirow[t]{3}{*}{$S \times 2$} & & 1202 & & & \\
\hline & & 12205 & * & & \\
\hline & & $\begin{array}{llll}1 & 2 & 0 & 8 \\
1 & 2 & 1 & 5\end{array}$ & ，暗角橧色 & & \\
\hline \multirow{4}{*}{ R 三 } & 推谷固 & 1210 & 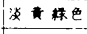 & 時* & Millammina ochigoensis \\
\hline & \multirow{6}{*}{ 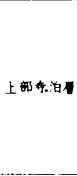 } & 12275 & 鈤 和 & & \\
\hline & & 1280 & 然 & & $\begin{array}{l}\text { Spirosigmoilinello } \\
\text { compresso }\end{array}$ \\
\hline & & 1290 & 淡維e & & Morinottielle communis \\
\hline $\begin{array}{lll}5 & k & 3\end{array}$ & & 1295 & 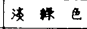 & & \\
\hline & & 1300 & $n$ & & Spirosigmoilinella \\
\hline & & 1305 & . & & Haplophre jmoid \\
\hline & 覀山石 & 1190 & 缕苚練 e & 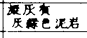 & 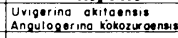 \\
\hline 北胃附 & & 1570 & 满色 & & Miliommto echigoonsis \\
\hline $\begin{array}{lll}S & k & 1\end{array}$ & 上护泊八 & 1575 & 㛀光程色 & 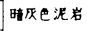 & Cyclammino joponica \\
\hline & & 1585 & : 党 & & Uvigering akitaensis \\
\hline & 垪虫 & 1505 & 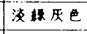 & 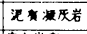 & $\begin{array}{l}\text { Happlophragmoides ctr. } \\
\text { subgrol oso }\end{array}$ \\
\hline $\begin{array}{lll}\pi & & \\
S & K & 1\end{array}$ & 事志 & 1510 & $n$ & 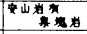 & Martinottiella communis \\
\hline & 开 & 1525 & $\therefore$ & 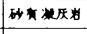 & $\begin{array}{l}\text { Mortinottiollio communs } \\
\text { Uv19ering so }\end{array}$ \\
\hline & & 14435 & 暗相质色 & & Angulogerina kokozur aensis \\
\hline & & 1440 & $\therefore$ & & Uvigering ekitoensis \\
\hline $5 k$ & 洪忠 & 1450 & 轫色 & 最厉 的若 & $\begin{array}{l}\text { Haplophragmoides ctr. } \\
\text { subgrolo so }\end{array}$ \\
\hline & & 1455 & - & & Bolivinito godrilotero \\
\hline & & 1465 & - & & \\
\hline & 西山 & 11155 & 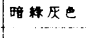 & 火砾㱠岩 & Uvigerino akitoensis \\
\hline & & $|1160|$ & $\therefore$ & & Anguloger rina kokozuraensis \\
\hline 小千谷 & & 1165 & 涹象质e & & 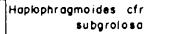 \\
\hline & & $1170 \mid$ & - & - & Martinottiellarcanmunis \\
\hline $\mathrm{s} \times \mathrm{K} 2$ & 虫忠 & 1175 & 睛标瓜色 & & \\
\hline & & 1190 & . & 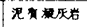 & \\
\hline & & 1225 & 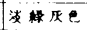 & 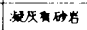 & \\
\hline
\end{tabular}

料を水でねり，ガラス㤆上に引作ばして定うj位皮膜を作 り，これを風乾したものをX線回折分析用試料とする。 また，試料の膨潤性をしらべるために，定方位試料を エチレングリコールに兴し，風乾したものについてX線 回折分析を行なっている。

\section{X 線回析分析法による海緑石の判定}

新潟油田地域坑扵産海綠石のX線回折法による分析の 結果は，第3図に示している。また，第2 表は各版州の 試料について，X線回折線図上にあらわれる特徴を示し ているものであり，淤緑石の（010）面について，それが

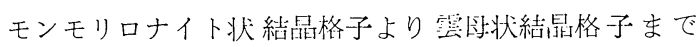
の，どの格子間喘に相当するかを时らかにしている。

\section{1. $\mathrm{X}$ 線回折線図上の特徵による海緑石の分類}

Burst $^{(3)}$ （1958）は，X線回折線図上にあらわれる特
第 2 図海緑不粒の顕微鏡写真

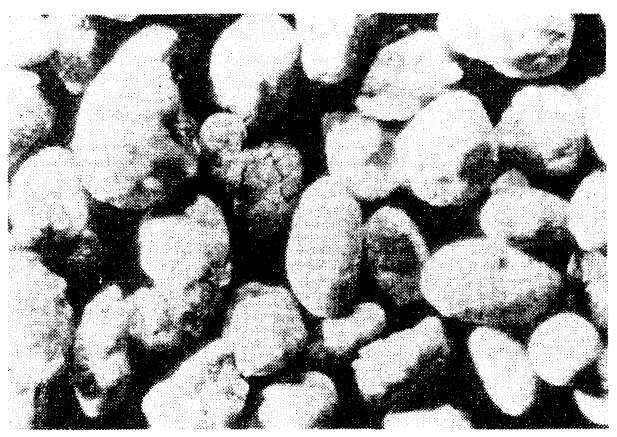

A 紫档寺 SK.1. $2100 \mathrm{~m}$ の試料 $(\times 20)$

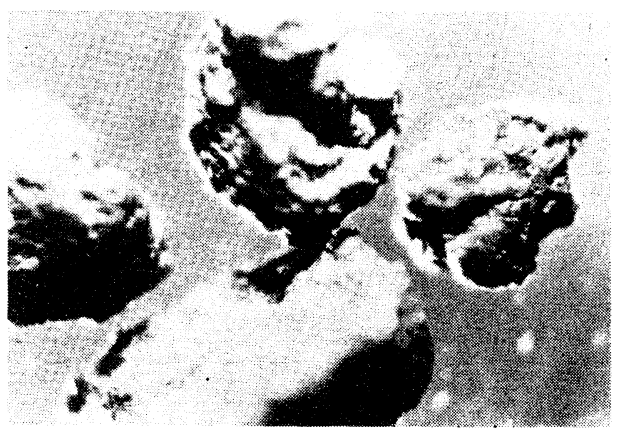

B 紫等寺 SK.3. $1580 \mathrm{~m}$ の试料 $(\times 20)$

徵，すなわち海緑不化の程度によつて示される結晶度の， 差より，海緑石を次のような 4 型に分類している。1) は舆型的な海緑石であり，非膨潤性雲时状の比較的良く 配列した結昆格子を持ち, ordered glauconite と称せら れる。2）は非膨潤性の監田状結昆格子を持つが，格子 配列が活れており，X 線回折線図上での強度が弱く, disordered glauconite と呼ばれている。3）は interlayered glauconite と言われるもので，極度に格子配列の悪 い膨潤性のモンモリロナイト状結鼠格子を持つものであ る。4）は海緑石以外に他の粘土鉣物が混在してるもの であり, mineral mixtured glauconite と名づけられてい る。

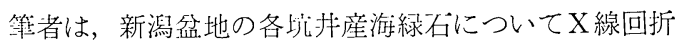
分析を行なった結果，これらにはモンモリナイト状結昆 格子を持つ interlayered glauconite の他に，イライトー モンモリロナイト琵合層状結昆格子を持つ海緑石が多い ことを見出し，これらをさらに細分する必要にせをられ たので，第3表の如き分類を行なっている。

この衣において Burst の分類と特に違っている点は, Burst の ordered 型海緑石と disordered 型海緑石とが, ともに具団状の非膨潤性鉱物であることより，これらを A 翋と大きく分類し，さらに格子配列の虔し瑟しにより ordered 型を $\mathrm{a}_{1}$, disordered 型を $\mathrm{a}_{2}$ と細分したこと， 
第 2 表 X 線回折分析法による解析結果
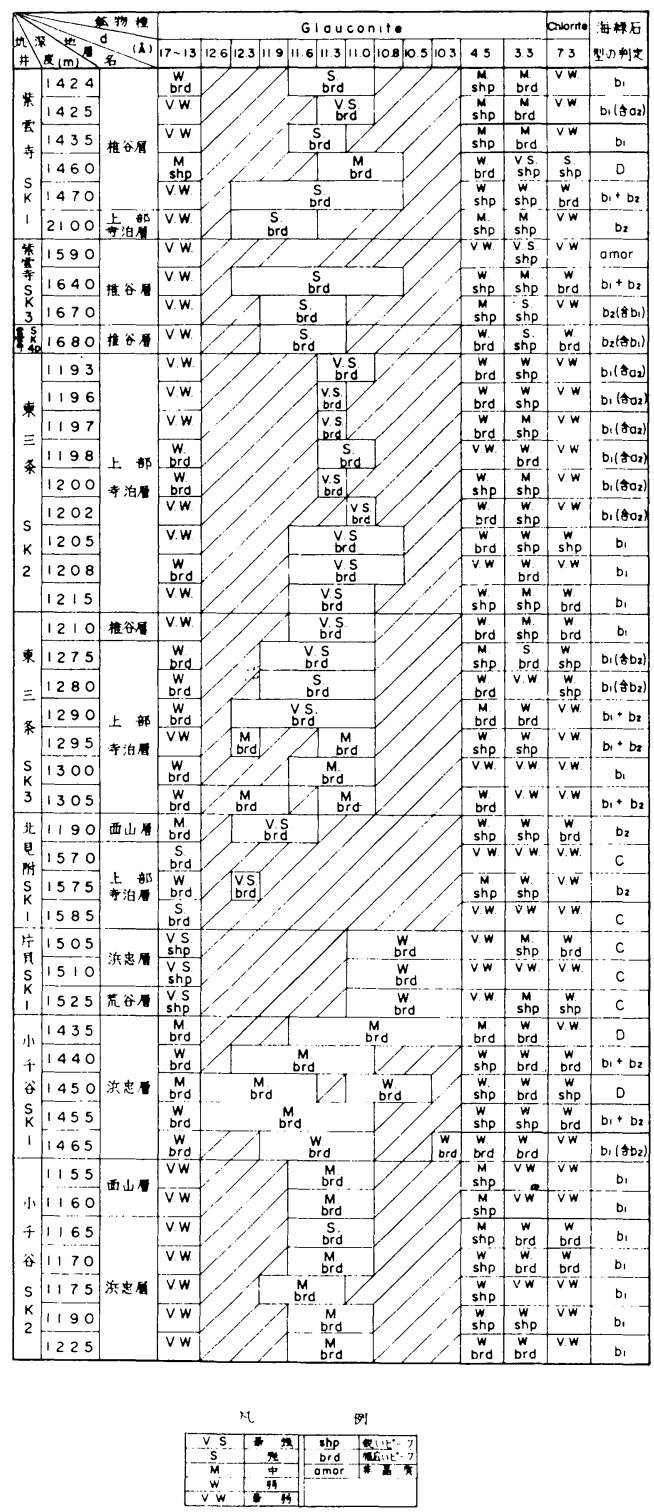

第 3 表 X線回折型による海線不の分類

\begin{tabular}{|c|c|c|c|}
\hline \multicolumn{3}{|r|}{$E^{*}-7$} & 回折型 \\
\hline \multirow{2}{*}{ A } & \multirow{2}{*}{\multicolumn{2}{|c|}{\begin{tabular}{l|l}
0. & 10.3 \\
0 & 10.8
\end{tabular}}} & 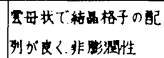 \\
\hline & & & 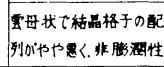 \\
\hline \multirow[b]{2}{*}{ B } & $b_{1}$ & $\begin{array}{l}10.8 \\
11.6\end{array}$ & 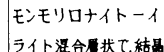 \\
\hline & $b_{2}$ & $\begin{array}{l}11.6 \\
12.6\end{array}$ & 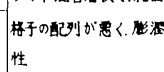 \\
\hline \multicolumn{2}{|c|}{$c$} & $\begin{array}{c}12.6 \\
5 \\
17.0\end{array}$ & 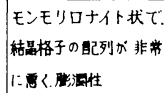 \\
\hline & & & 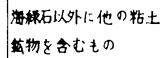 \\
\hline
\end{tabular}

第 3-a 図紫等寺 SK.1 缠海緑石のX線回折線図

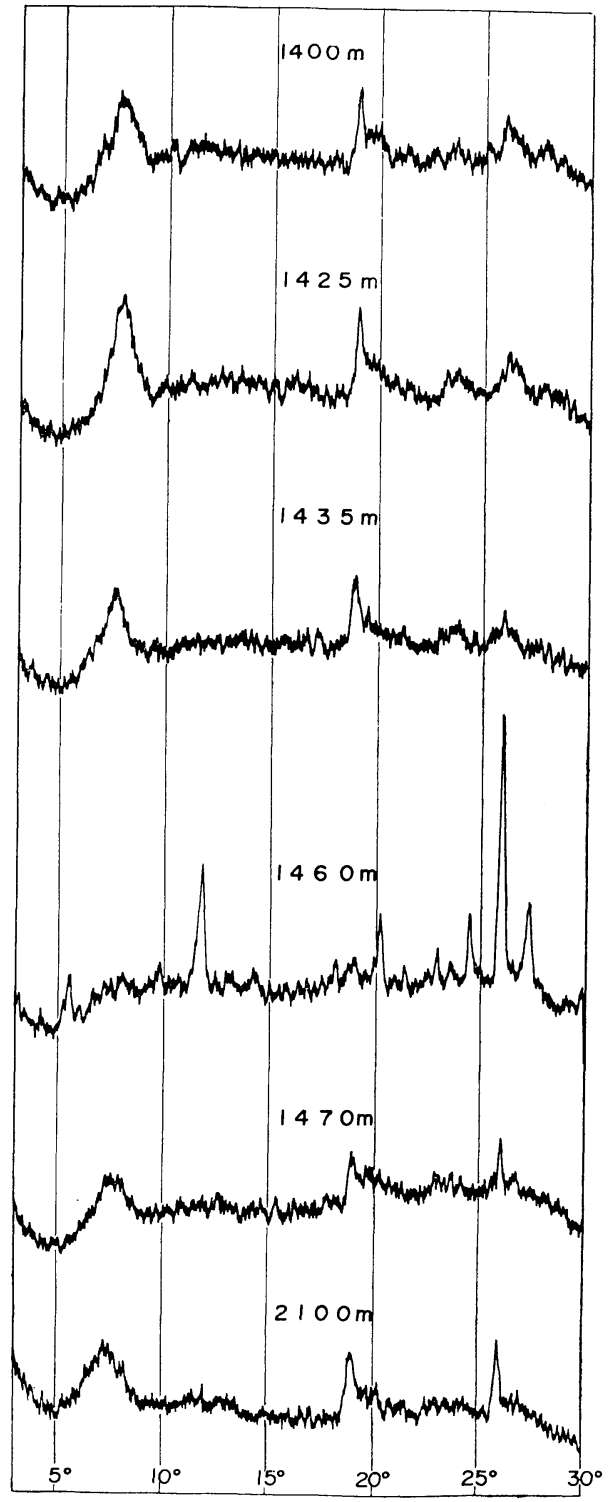

ならびに䇪㔹状海緑石とモンモリロナイト状海緑石との 中問にモンモリロナイトーイライト混合澢状海緑不を B $\left(b_{1} \cdot b_{2}\right)$ として分類したことである。

\section{2. 各坑井産海緑石の解析結果}

紫空专: SK.1 産の海線石は, $\mathrm{b}_{1} \cdot \mathrm{b}_{1}\left(\right.$ 含 $\left.\mathrm{a}_{2}\right) \cdot \mathrm{b}_{1}+\mathrm{b}_{2} \cdot \mathrm{b}_{2}$ ·D など種々の型があり，その海緑石化の程度が複雑で あること，および $3.3 \AA$ と $4.5 \AA$ のピークが比較的発 達していることが特徵になっている。これらのうち, 上 部の 1,424〜1,434 $\mathrm{m}$ の試料は主として $\mathrm{b}_{1}$ 型であり, 回折線頂部の幅がせまく, 海緑石化はやや進んでいるも のと思われる。これに対し下部の 1,460 2,100 m の淤 
第 3-b 図 紫雪寺 SK.3 商海緑不のX線回折線図

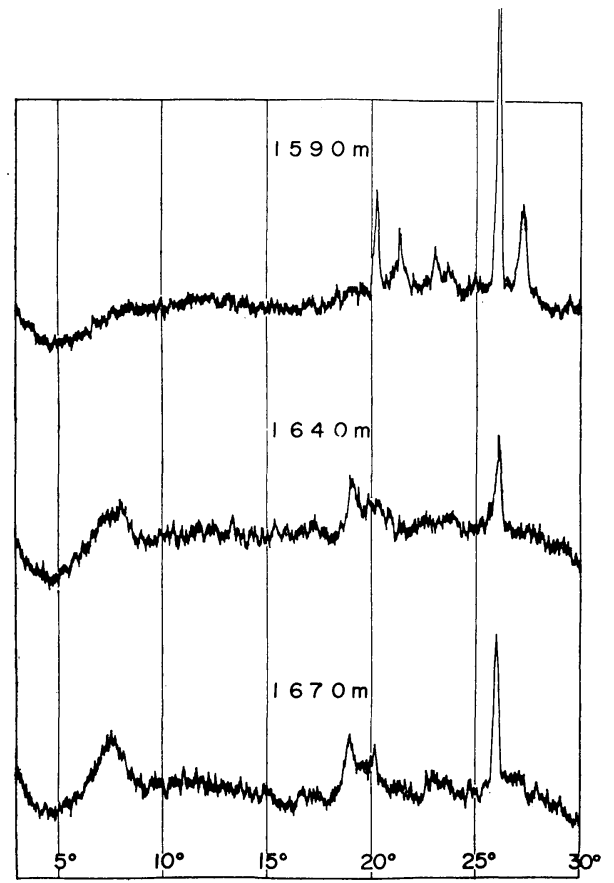

第 3-c 図 紫雲寺 SK-3D 産海緑石の X線回折線図

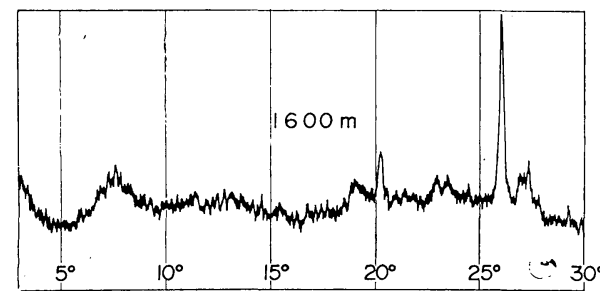

緑石はいずれも b2 型に属するもので，回折線頂部の幅 が広いかまたは弱く，海緑石化は上部に比して遅れてい ると考えられる。また $1,460 \mathrm{~m}$ の試料は，海緑石の （010）面のピークが比較的弱いのに対し，モンモリロナ イトの（001）および緑泥石の（002）面の回折線（17〜 13 拈よび $7.3 \AA$ ) が比較的強く，これらの鈗物の混在が 認められるので, Burst の mineral mixtured glauconite （D 型）であろうと判定している。

紫雲寺: SK 3 の 1,640・1,670 m の海緑石はともに紫 雲寺 SK 1 の下部に類似している。すなわち $b_{1}+b_{2}$ 型 および $b_{2}\left(\right.$ 含 $b_{1}$ ) 型で，いずれも $b_{2}$ 型の海緑石であ

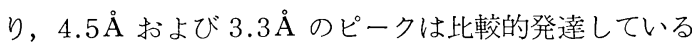
が，海緑石化は未だ初期の段階のものであると考えられ る。また $1,590 \mathrm{~m}$ の試料は，(010）面の発達がないた め，非晶質鉱物であると思われる。

紫雲寺 SK. $4 \mathrm{D}$ の試料女紫零寺 SK. 1 の下部と同様
第 2-d 図 東三条 SK.2 浐海緑石のX 線回折線図

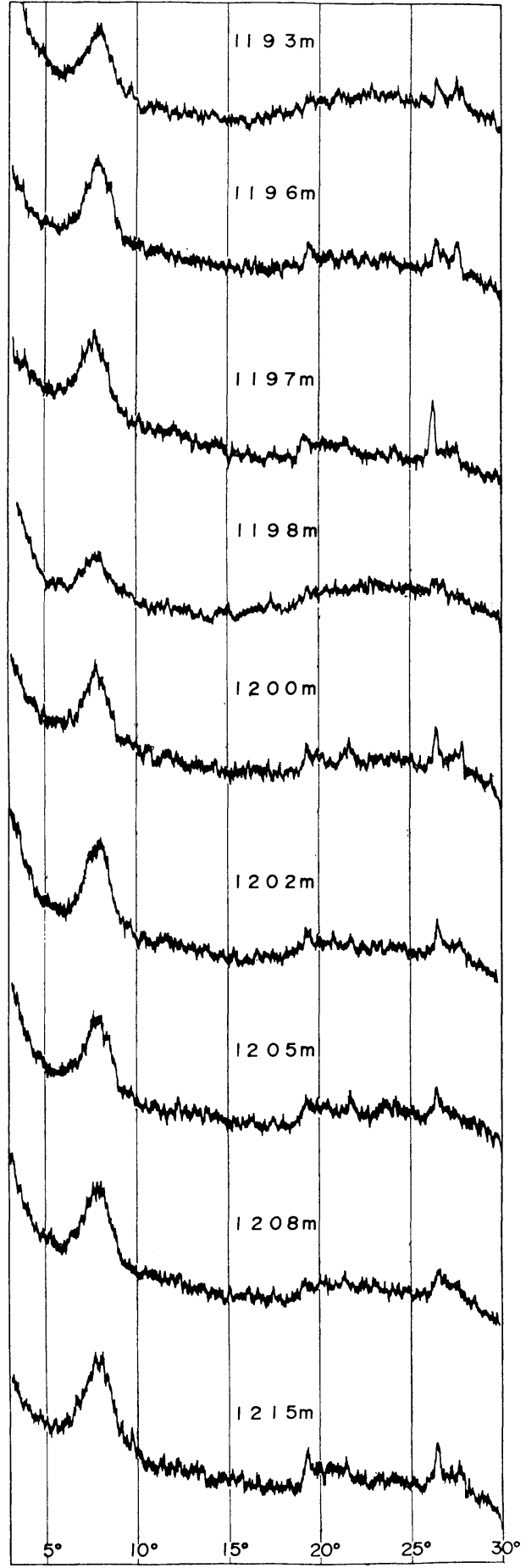

な $\mathrm{b}_{2}$ ( $\mathrm{b}_{1}$ 含) 型であり，その（010）面の頂部幅は 11〜 $12 \AA$ と広いが， $4.5 \AA$ 打よび $3.3 \AA$ のピークは比較的 発達しており，ごく初期の段階の海緑石であることを示 
第 3-e 図 東三条 SK.3 迹海緑不のX線回折線図

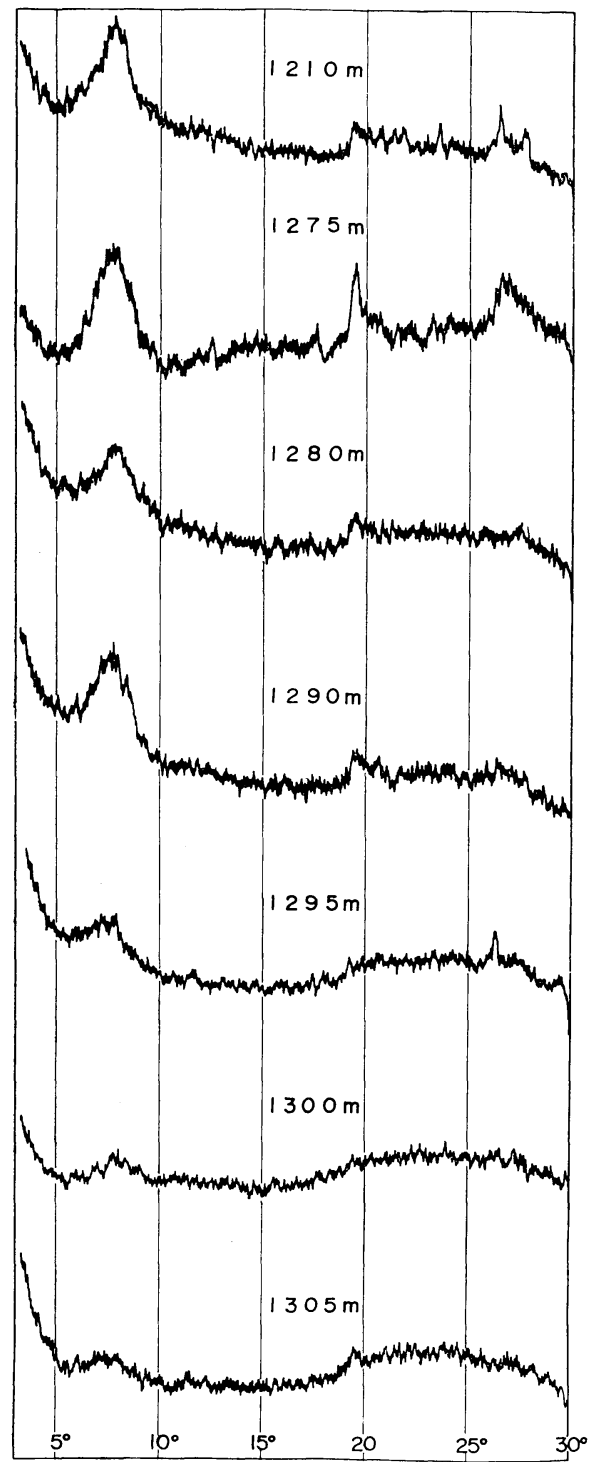

している。

東三条 SK. 2 の仼料は，いずれも $11.6 \sim 10.8 \AA$ の 強く幅広い回折線支持ち, $4.5 \AA$ と $3.3 \AA$ の回折線がー 段と強くなっていることが特徽である。これらは新潟盡 地坑井産の海緑石中もっとも海緑石化が進んだものと考 えられるが，エチレングリコール処理の結果によると， いずれも膨潤性であることが判明している。またこれら をさらに細分すると, $1,193 \sim 1,202 \mathrm{~m}$ と $1,205 \sim 1,215 \mathrm{~m}$ との上，下部 2 型に分けることができる。上部型の海緑 石は下部のものに対して 回折線頂部幅が 11.0〜 11.3 とせまく，さらに幾分鋭くなっており，海緑石化のやや
第 3-f 図北胃附 SK.1 座海緑不のX線回折線図

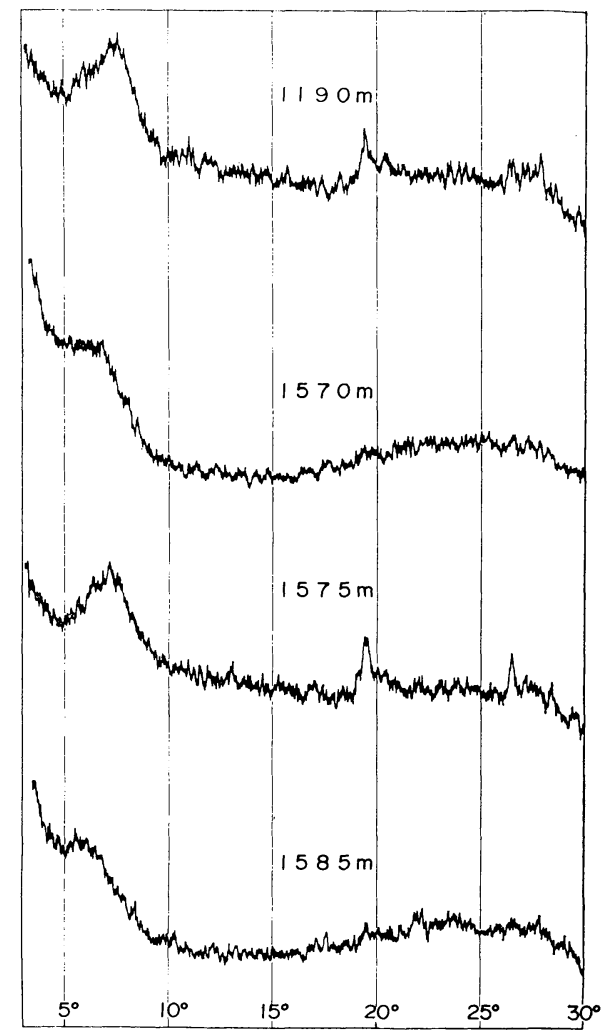

進んだ雲拇型に近い $b_{1}$ （含 $a_{2} ）$ 型であり，下部型はそ れとは逆に，頂部幅が $10.8 \sim 11.6 \AA$ とやや幅広い典型. 的なモンモリロナイトーイライト混合嘱型（ $b_{1}$ 型）を呈 している。

東三条 SK. 3 の海緑不は東三条 SK. 2 と同様に $b_{1}$ 型が主体となっているが，さらに 3 型に細分することが できる。1 1 1,210 $\mathrm{m}$ および 1,300 $\mathrm{m}$ の型で，11.0〜 $11.6 \AA$ の強い回折線を持つ興型的な $\mathrm{b}_{1}$ 型である。2 の 型は $1,275 \cdot 1,280 \mathrm{~m}$ の試料の如く, $\mathrm{b}_{1}$ 型と類似しては いるが， b 型の形態をも備えるもので，1 の型より海緑 石化のやや遅れた結晶形態を持つ $b_{1}$ (含 $b_{2}$ ) 型である。 3 は $1,290 \cdot 1,295 \cdot 1,305 \mathrm{~m}$ の試料にみられる型で, $\mathrm{b}_{1}$ 型 と $b_{2}$ 型の混合形態をなすものであり, これの特徵は,

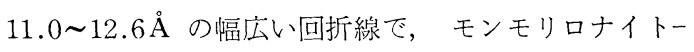
イライト混合層状の結晶形態を持つことである。

北見附 SK. 1 の海緑石には， 1,190・1,575 m と $1,570 \cdot 1,585 \mathrm{~m}$ との 2 種類の型が存在する。 1,190 ・

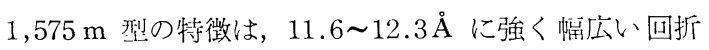
線を持つ少型的な $\mathrm{b}_{2}$ 型であり,この型の海緑石はモン モリロナイトーイライト混合称状の結昆形態をとってい る。1,570・1,585 m 型の特徴は, $13 \sim 17 \AA$ の幅広い回 
第 3-g 図 故只 SK.1 商海緑不のX線回折線図

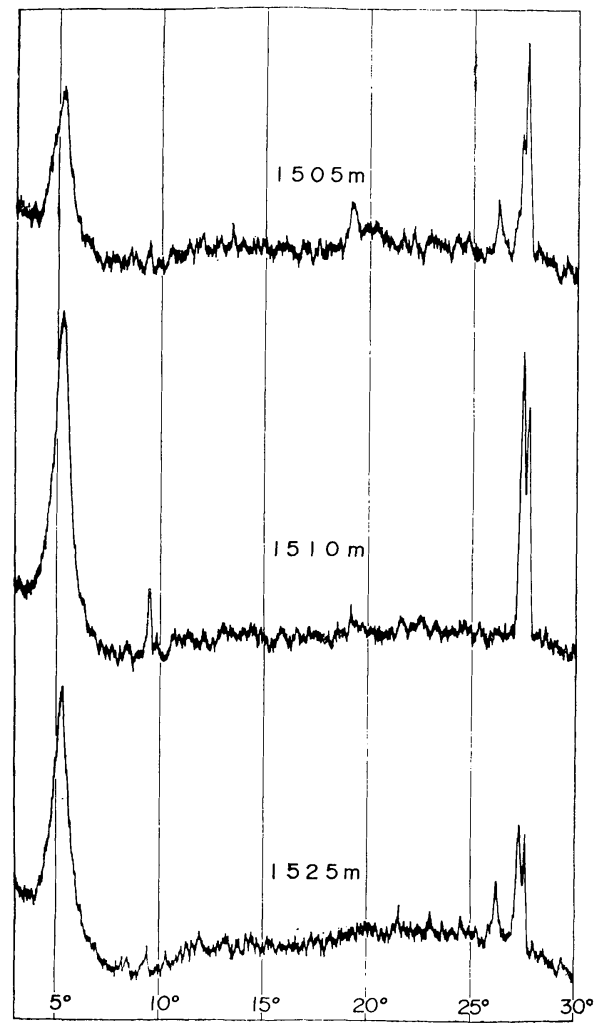

折線であり，これは極度に格子配列の悪いモンモリロナ イト状結昆格子を持つ海緑石であることを示しており， Burst $の$ interlayered glauconite (C 型) の典型的な例 である。

片貝 SK. 1 産の試料にみられる特敷は, モンモリロ ナイトの（001）面状の強く鋭い回折線を持つことであ り，結昆格子の配列が非常に乱れた，ごく初期の段階の 海緑石であることを示しているが，それ以外に海緑石の 10.3 11.0 の の弱く幅広い回折線および $3.3 \AA$ のやや 鋕い回折線が喼められるので，典型的な interlayered glauconite よりはわずかに進化したC型の海緑石であろ うと思われる。

小干谷 SK. 1 の海緑石には, 二つの型が認められる。 1 つは $1,435 \cdot 1,450 \mathrm{~m}$ にみられる回折型で， 13 17 の幅広い回折線抢よび 10 12 の非常に幅広い回折線 を持つ型であり，これはモンモリロナイトーイライト混 合䁲状海緑石以外にモンモリロナイトをも含む $\mathrm{D}$ 型の mineral mixtured 型海緑石である。もう 1 つは 1,440 . 1,455・1,465 m の型であり，これは典型的な $\mathrm{b}_{1}+\mathrm{b}_{2}$ 㤠 の海緑石である。そしてモンモリロナイトの回折線が発 達せず，また海緑石の回折線頂部幅もややせばまってい
第 3-h 図 小千谷 SK.1 疾海緑不のX X 線回折線図

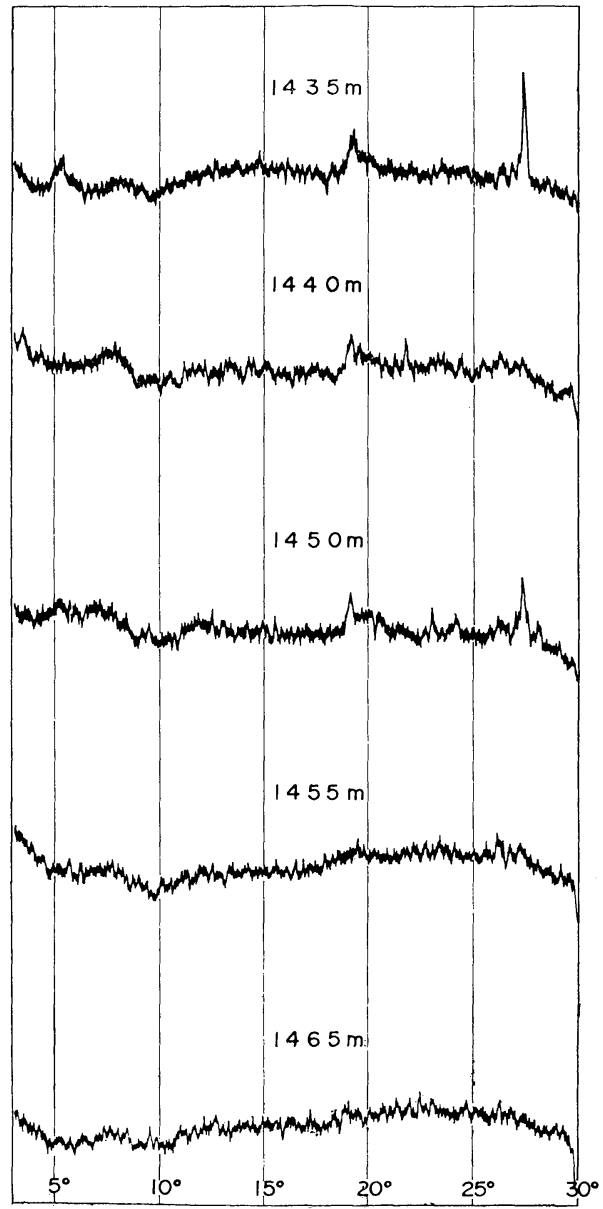

る点からみて，その海緑石化は前者よりもやや進んでい ると思われるが，これも結晶格子的にはかなり配列の覀 いものである。

小千谷 SK. 2 産海緑石の特徴は，第三条 SK. 2 の 下部型に類似した期型的な $b_{1}$ 型のモンモリロナイトーイ ライト混合層状結昆格子を持つことであり，その（010） 面はいずれも幅広いが，かなり強い回折線を示してい る。小千谷 SK. 1 の海緑石に比して, これらの試料の 海緑石化は数段と進歩しており，また新潟潟盆地産の海 緑石の中でも, 結昆格子の配列のかなり良いものであ る。

\section{4. 海緑石の形成とその堆積環境亡の関連}

海緑石は，他の粘土鉱物に比して特にその形成時の環 境に左右され易く，堆積時およびその後の唯積条件の変 化にしたがって，それに適合した形態の海緑石が形成さ れていくと考えられている。 
第 3-i 図 小千谷 SK.2 群海緑不のX線回折線図

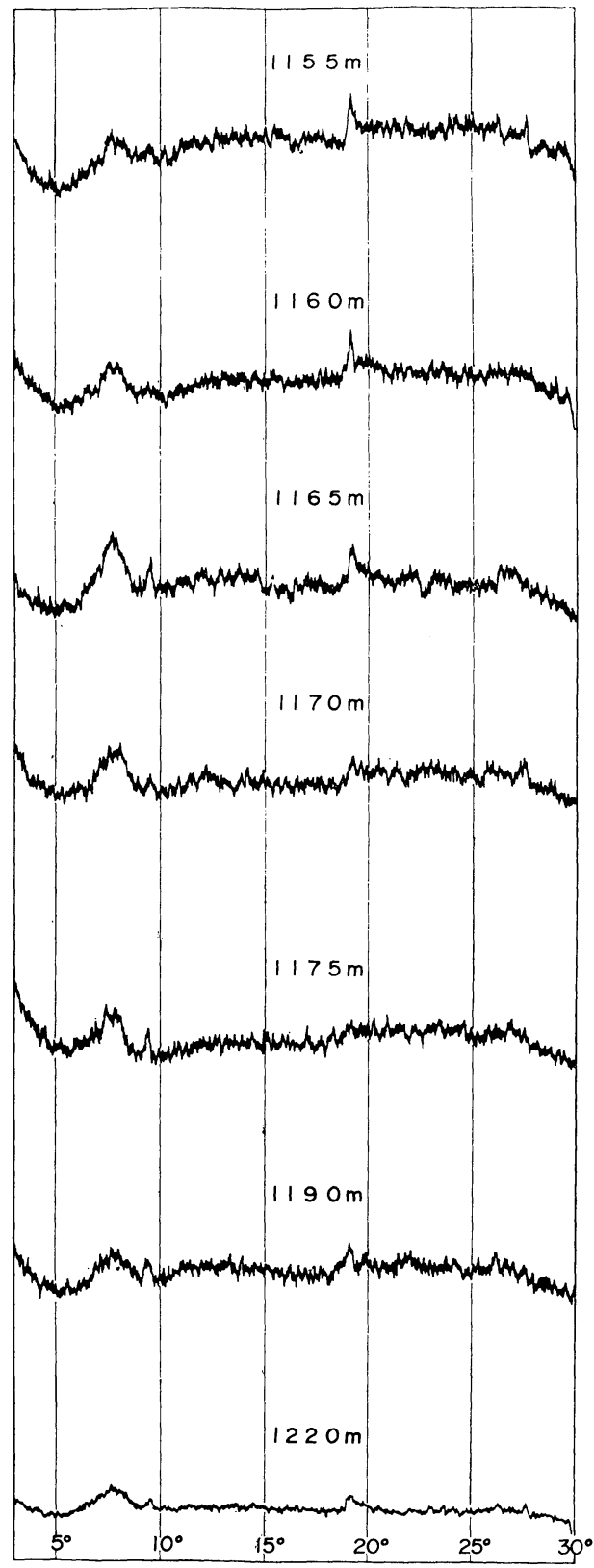

筆者は, 海緑石の形成に関する多くの研究者達の報告 ならびに地質学的・古生物学的な資料に基づき，いくつ かの坑井に産する海緑石について，その形成に影響を及 ぼすと考えられる堆積䍗境との関連について考察してみ た。

4.1. 紫雲寺 SK. $1 \cdot S K .3 \cdot$ SK. $4_{\mathrm{D}}$ の椎谷層に産す る海緑石

これらの坑井に産する海緑石は, 前述した如く, 主と
して $b_{1}$ 型であり，海緑不化は余り進んでいない。第 1 図でも明らかなように，これらの坑井の椎谷䡍は非常に 撔く，その岩相は喑灭色凝灭質泥岩で比較的一定してい る。しかし非笝に凝灭澌であり，粘土鉣物分析結果 ${ }^{(2)} に$ よると，モンモリロナイトが 60〜90\% を占めるような 厏相である。またこれらの試料は，有孔虫の資料によれ ば, upper bathyal zone に堆積されたと考えられている。 これらの資料により，海緑石の形成とその堆積時の環境 との関連を考察してみると, まず海緑石の村材としては, 围宦にモンモリロナイトの多いことならびにこれらの海 緑不の結品形態が悬拇よりモンモりロナイトに近いこと よりみて，モンモリロナイトを多く含むような凝咸質物 質であったと考えて良いであろう。なお，この凝死岩よ り海緑不への変質については，北崎・市田 ${ }^{(6)}$ (1951) が 能登地方の海緑石において詳細に論じている。この凝灰 質囦材は，岩相に示されるような有機物量の多い bathyal zone に堆積されたと考えられるが，この地域は鯨岡(7) （1962）によると椎谷期の沈降部に近く，したがって堆 積速度が比輍的速く，しかも海水との接触時間が短かか ったと考えられるので，海緑石の形成にはやや不利であ り*，これが海緑石化の未発達な最大の原因であると思 われる。

\section{2. 東三条 SK. $2 \cdot \mathrm{SK} .3$ の上部寺泊層に産する海} 緑石

東三条 SK. 2 の 1,193 1,198 m の試料は凝灰岩・ 泥岩互竭中より，また 1,200〜 1,215 $\mathrm{m}$ の試料は喑灰色 泥岩中より得られたものである。これらの海緑石は上部 が $b_{1}$ (含 $a_{2}$ ) 型，下部が $b_{1}$ 型といずれもかなり海緑 石化が進んで拈り，とくに上部型は全ての試料中もっと も海緑石化の進んだものである。また SK. 3 の試料は， いずれも均質な黒色泥岩中に産しており，ややその型に 差簧があるが，ほぼ類似した $b_{1}$ 型の海緑石である。こ れらの涗打の上部洔泊層は，他地域のそれに比して $40 \mathrm{~m}$ 内外と非常に薄く，これは竹内 ${ }^{(9)}$ (1962) によると，こ の地域が七谷期の volcanic centre であり，寺泊期には これを反咉した uplift 域となっていたためと考えられ る。しかし，有孔虫の資料は， deep stagnant zone の環 境を示しているので，部分的にはかなりの起伏があった ものと推定される。

これらの資料より，堆積時に抢ける種々な海緑石の母 材は，部分的にやや深いが海流の動きの余りない，しか も堆積物流入量のかなり少ない嫌気性の罢境に堆積され

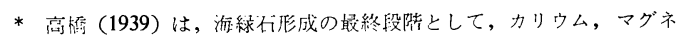

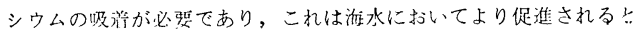
述べている。
} 
たと考えられるので*，目材が海水と掊触する時間はや や長く，したがって海緑石の形成には好都合でありここ れが此較的結晶度の良い海緑石をもたらす原因であった と思われる。これらの海緑石間のわずかな差巽は，堆積 時に㧍けるそれぞれの環境にやや差があり，海水との接 触時間, 堆積速度などの堆積条件に変化があったためと 考えられる。

\section{3. 北見附 SK. 1 の上部寺泊層に産する海緑石}

この坑排の上部寺泊㯽に産する海緑石は，暗灰色泥岩 中より得られた $b_{2}$ 型および $C$ 型のものである。寺泊期 のこの地域は, 竹内 ${ }^{(9)}$ (1962) によると, やはり七谷期 の volcanic centre を反映したテラス状の海域であった が，むしろ沈降部に近く，やや深かったと考えられてい る。また有孔虫の資料は，この地域が upper bathyal zone であったことを示している。さらにこの地域の上部持泊 層の泥岩は，粘土鉱物分析の結果によると ${ }^{(2)}$, やはりモ ンモリロナイトをかなり多く含んでいる。そして，これ らの海緑石がモンモリロナイトーイライト混合屑に類似 の結昆形態を有することを加味すると，これらの海緑石 の母材としては，紫雲寺 SK. 1 などにおける場合と同 じく，凝灭質物質と考えることがもっとも妥当である。 これらの母材は, やや公海性の堆積速度のかなり早い平 穏な環境に堆積されたため, 海水との接触を充分にうけ ることができず，これが海緑石化の発達しなかった原因 であろうと思われる(8)。

\section{4. 片貝 SK. 1 の浜忠層に産する海緑石}

これらの海緑石は，泥質凝扊岩および安山岩質集塊岩 中に産するものであり，いずれもモンモリロナイト状結 唱格子を持つC型である。竹内 ${ }^{(9)}$ (1962) は, この西山 期においては棑谷期に形成された堆積盈地の分化が著る しく，その基底部は公範囲にわたり顕著な不整合が認め られ，また火山活動が活発で局地的に多量の溶岩や集塊 岩が堆積されたと述べている。しかし，この片貝地域は 堆積盈地の中心に近く，しか子有孔虫の資料にみられる 如く deep stagnant zone であったと思われる。したが って，海緑石の目材は，形成に有利な嫌気性で海流の動 きのない環境に堆積されたが, 堆積速度が早く, 海水と の接触を充分にうけることができなかったと推定され， これが海緑石化作用に負の影響をもたらしている原因な のであろう。な捛，火成岩迸入の影響が海緑石化作用に どのような変化を与えるかは明らかでないが，少なくと も正の方向のものであるとは思われない。

*Cloud(4) は, 海緑石の形成には環元的状態を必要とするので, 酸 菜供給鼠の少ない腐散不機物量の多い嫌父性の壊境の方が，海緑不 の形成に有利であると述へてている。

\section{5. 小千谷 SK. 1.SK. 2 の西山層（浜忠層）に産 する海緑石}

小千谷 SK. 1 の北料は, 凝灰質砂岩より産した, い ずれ女良く類似した $\mathrm{D} \cdot \mathrm{b}_{1}+\mathrm{b}_{2} \cdot \mathrm{b}_{1}$ （今 $\mathrm{b}_{2}$ ）型の海緑石で ある。また SK. 2 の試料は, 火磍質砂岩, 泥質凝成岩, 凝灰質砂岩より得たもので，いずれも典型的な $b_{1}$ 型の 海緑石である。この小千谷地域は, 片貝地域と近接して いるが, 岩相でも明らかなように西山期の volcanic centre よりやや離れていたと考えられる。また有孔虫の資料よ りその環境は lower neritic〜upper bathyal とやや浅く, しかもむしろ公海性のものであったと推定されている。 これらの海緑不の母材は，他の坑井の試料と同様に，や はり火山砕屑物であったと考えられるので, 片貝 SK. 1 ・ 小千谷 SK. 1·SK. 2 に打ける海緑石の差異を規定する ものは, 恐らく堆積環境の相違と火山の影喑であったと 考えられ，この点より判断すれば，公海性の環境および 火川.作用は海緑石化作用に負に，浅い深度は正に働いた とみるのが妥当である。

\section{5. 海緑石による地層対比の問題}

\section{1. 西山層（浜忠層）について}

これらの各坑井において西山層（浜忠層）より得られ た海緑石は，北見附 SK. 1・片貝 SK. 1・小千谷 SK. 2 の試料である。これらの海緑石の母岩は, 片貝 SK. 1 の $1,510 \mathrm{~m}$ の試料が安山岩質集塊岩である以外はいず れも凝灰質砂岩または泥岩であり，岩相上大きな変化は 認められず，また有孔虫による対比も充分可能である。 しかるに，これらの海緑石はそれぞれ $\mathrm{b}_{2} \cdot \mathrm{b}_{1} \cdot \mathrm{C}$ 型とかな り異なっており，むしろそれぞれの地域や各坑井毎の特 徵が顕著にみられる。

\section{2. 椎谷層 (荒谷層) について}

椎谷層（荒谷層）は，紫䨋寺 SK. $1 \cdot \mathrm{SK} .3 \cdot \mathrm{SK} .4 \mathrm{D}$, 東三条 SK. 3 および片貝 SK. 1 の各坑井において認め られる。これらの岩相は, 凝灭質砂岩および泥岩であり, 古生物学的にもそれほど差異が認められない。しかし， これらの各坑井の海緑石は，これに反して， $b_{1}\left(\right.$ 含 $\left.\mathrm{a}_{2}\right)$. $\mathrm{b}_{1} \cdot \mathrm{a}_{1}+\mathrm{b}_{2} \cdot \mathrm{C} \cdot \mathrm{D}$ 型と非常な変化を示している。

\section{3. 上部寺泊層について}

上部寺泊層の試料は, 紫笓寺 SK. 1, 東三条 SK. 2 . SK. 3, 北見附 SK. 1 の各坑扭に分布している。これら の各果岩の岩相は，特徵のある暗死〜黒色泥岩であり， また有孔虫化石の資料においてもさしたる変化は認めら れない。これらの坑井に産する海緑石には， $b_{1}$ (含 $\mathrm{a}_{2}$ )・ $b_{1} \cdot b_{1}\left(\right.$ 含 $\left.b_{2}\right) \cdot b_{1}+b_{2}$ 型など $b_{1}$ 型が多く認められるが， $\mathrm{b}_{2} \cdot \mathrm{C}$ 型も見出すことができる。そして大まかな見かた をするならば，東三条 SK. 1 と SK. 2 とはともに b 
型で良く似て抢り，北見附 SK. 1 ( $\mathrm{b}_{2}$ 型)，紫䍃持 SK.

2 ( $\mathrm{b}_{2} \cdot \mathrm{C}$ 型) などとかなり異なっていると言えよう。

以上の邚く，新潟盈地の各瀜準に産する海緑不は，同

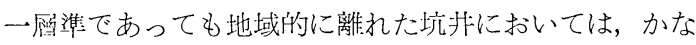
りその型が異なっている。そして，同一櫫準で堆積環境 の等しいような近距離の坮井間の海緑石，またはむしろ 同一坑井の近い層準に産する海緑石においてのみ，その 形態が類似することが多い。これは $\mathrm{Cloud}^{(4)}$ (1951) が 述へているように，“類似した堆積環境においてのみ類 似の海緑石が形成される”ことを裹附けるものに他なら ない。したがって，游緑石による対比は，ある堆積時期 において堆積環境の変化が起らないような広い堆積盆地 内においてのみ有効であり，堆積盆地の分化が激しく， 離れた地域間の堆積環境が基なるような場河では，適用 することが困難になってくる。

\section{6. 結 論}

新潟油田地域の 9 坑求の 新第三系堆積岩より鷹した 45 個の海緑不試料について，光学的観察ならびに X 線 回折法による分析を行ない，次のような結果を得た。

（1）これらの海緑不は，通常光沢のある䰻緑色〜青 黄緑色の不透明な粒子であり，主として球形で裂片を持 ち, $0.5 \mathrm{~mm}$ 以下のものと $1 \mathrm{~mm}$ 以下のものとの 2 種類 が認められた。

（2）X線回折分析の結果に基づき，新潟盈地産の海 緑石を, 型状状の $\mathrm{A}\left(\mathrm{a}_{1} \cdot \mathrm{a}_{2}\right)$ 型，モンモリロナイトーイ ライト混合層状の $\mathrm{B}\left(\mathrm{b}_{1} \cdot \mathrm{b}_{2}\right)$ 型，モンモリロナイト状の C型，鉱物混合の D型の 4 型に分類した。

（3）これらの海緑石は，B抢よびC型が多い。すな わち，紫零专 SK. 1 の椎谷層は $b_{1} \cdot b_{1}\left(\right.$ 念 $\left.a_{2}\right) \cdot b_{1}+b_{2}$. $\mathrm{D}$ 型であり，上部寺泎㕆は $\mathrm{b}_{2}$ 型である。紫䨝侍 $\mathrm{SK} .3$ の椎谷尿は $b_{2}\left(\right.$ 今 $\left.b_{1}\right) \cdot b_{1}+b_{2}$ 型である。紫零寺 SK. $4 \mathrm{D}$ の椎谷層は $\mathrm{b}_{2}$ (会 $\mathrm{b}_{1}$ ) 型である。東三条 SK. 2 の上部 寺泊缐は $\mathrm{b}_{1}$ (会 $\left.\mathrm{a}_{2}\right) \cdot \mathrm{b}_{1}$ 型である。身三条 SK. 3 の棑 谷層は $b_{1}$ 型，上部寺泊珰は $b_{1} \cdot b_{1}\left(\right.$ 含 $\left.b_{2}\right) \cdot b_{1}+b_{2}$ 型で ある。北見附 SK. 1 の西山厤は $\mathrm{b}_{2}$ 型，上部寺泊原は $\mathrm{b}_{2} \cdot \mathrm{C}$ 型である。片貝 SK. 1 の呮忠原，荒谷原は C 型 である。小千谷 SK. 1 の泬忠㿣は $b_{1}\left(\right.$ 念 $\left.b_{2}\right) \cdot b_{1}+b_{2}$. $\mathrm{D}$ 型である。小千谷 SK. 2 の四山層（浜忠原）は $\mathrm{b}_{1}$ 型 である。
（4）これらの海緑不の厓材は，火山䂗屑物が多かっ たものと推定される。

（5）これらの海緑不は, upper bathyalzone に堆積 されたものが多いが, deep stagnant zone, lower neritic zone の場合もある。

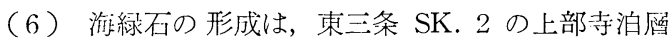
中の海緑石の如く，嫌気性で有機物量が多く，しかも堆 積速度が遲くて堆積物量が少く，海水との接触を充分に うけることの出来る環境がもっとも有利である。

（7）海緑不による地䝠対比は，その内部で堆積環境 の変化が起らないような陫積䓝地内に掞いてのみ有効で ある。

謝辞 本論文の公表を許可された石油資源開発(株)技 術研究所越前屋卯一所長に感謝するとともに，日頃常に 御指導・御討諭をしていただいている同所岩本寿一主任, 渡辺烡久男，工藤修治氏らに曆く御礼を申し上げる。ま たこれらの試料を提供していただいた同社長岡鉱業所 新保久弥氏らに深見の謝意を表する。

\section{参考文献}

（1）青柳宏一（1963）：新鼬盆地含油新第三系堆積岩 巾の海緑不について，不油開発技研所報，Vol. 7, No. 1.

（2）青柳宏一（1964）：X線回折法による本邦油咕地 域堆積岩の鈗物学的研究, 石油開発技研特報, No. 21.

(3) Burst J. F. (1958): "Glauconite”, Pellets: Their Mineral Nature and Application to Stratigraphic Interpretation, Bull. A.A.P.G., Vol. 42, No. 2.

(4) Cloud P. E. (1955): Physical Limit of Glauconite Formation, Bull. A. A.P.G., Vol. 39, No. 4.

（5）樹下 惺（1962）：裹日本含油新第三系堆積岩の 粘土鉙物層序と海緑不について，粘土科学の進歩 (4)，技報堂

（6）北崎梅香・市田莣子（1951）：能登地方の海緑石 について，資源研巢報，19２1 号

（7）鯨岡 明 (1962)：荒谷相の意味するもの，石技 誌, 27 巻, 6 号

（8）須藤俊努（1953）：粘土鉿物，峟波書店

（9）竹内㕇彦（1962）：新潟県中部に打ける油田の生 成に関する研究，石技誌，27 卷，6 号 